\title{
PERMINTAAN TAMBAHAN TARIF JASA KURIR DALAM BISNIS DELIVERY ORDER DI KOTA LANGSA (TINJAUAN ETIKA EKONOMI ISLAM)
}

\author{
Muhammad Firdaus ${ }^{1}$, Omar Rahadian ${ }^{2}$
}

\begin{abstract}
Delivery order is an inter-messaging service, in its mechanism, the customer called the admin delivery to order an item desired and the admin to forward the order via what's app to the courier. But in practice, the courier sometimes asks for additional fee courier services to consumers for a variety of reasons. The issue in this study, how is the practice additional requests for courier services in order delivery business in Langsa city and how the Islamic economic ethics reviews against additional requests for courier services in delivery order business in Langsa city. This type of research is field research. The results of this research shows, the practice additional fee courier services to consumers is the consumers feel lied. The additional fee practice of courier services is reviewed according to Islamic law is not yet qualified, because in practice the addition of fee made to make consumers or customers are less willing to feel disadvantaged because there is no prior notice (gharar), so the consumer or costomer is forced to pay. In Islam, it has been explained that one of the two people is forced to do the contract, so the contract is not valid.
\end{abstract}

\section{Keywords: Delivery order, Etika, Ekonomi Islam}

\section{Pendahuluan}

Agama Islam merupakan agama yang diturunkan oleh Allah SWT ke muka bumi untuk menjadi rahmatan lil alamin (rahmat bagi seluruh alam), Islam tidak hanya sekedar mengatur masalah ibadah seorang hamba kepada Tuhan-Nya, tetapi juga mampu menjawab berbagai macam bentuk tantangan pada setiap zaman, termasuk dalam persoalan ekonomi, yang kenal saat ini dengan istilah Ekonomi Islam.

${ }^{1}$ Penulis adalah Dosen Hukum Ekonomi Syariah Institut Agama Islam Negeri Langsa, Email: mfirdaus@iainlangsa.ac.id

${ }^{2}$ Penulis adalah Alumni Hukum Ekonomi Syariah Institut Agama Islam Negeri Langsa, Email: omar.rahadian@gmail.com 
Ekonomi Islam dibangun atas dasar agama Islam, karenanya ia merupakan bagian yang tak terpisahkan (integral) dari agama Islam. Sebagai derivasi dari agama Islam, ekonomi Islam akan mengikuti agama Islam dalam berbagai aspeknya. Ekonomi, secara umum didefinisikan sebagai hal yang mempelajari perilaku manusia dalam menggunakan sumber daya yang langka untuk memproduksi barang dan jasa yang dibutuhkan manusia (P3EI: t.t.: 13). Ruang lingkup ekonomi meliputi satu bidang perilaku manusia terkait dengan konsumsi, produksi dan distribusi.

Menurut sumber-sumber literatur mengatakan bahwa, etika ekonomi didasari oleh ajaran-ajaran agama. Dalam pelaksaan etika bisnis ada beberapa prinsip yang harus dianut oleh pelaku bisnis. Prinsip etika atas sikap jujur yang harus dimiliki oleh pelaku bisnis merupakan prinsip penting, bahkan prinsip ini merupakan modal utama bagi pelaku bisnis manakala diinginkan bisnisnya mendapat kepercayaan dari partner dan masyarakat.

Sebagai makhluk sosial, manusia tidak bisa lepas untuk berhubungan dengan orang lain untuk memenuhi kebutuhan hidup. Kebutuhan manusia sangat beragam, sehingga secara pribadi tidak mampu untuk memenuhinya, dan harus berhubungan dengan orang lain. Hubungan antara satu manusia dengan manusia lain dalam memenuhi kebutuhan, harus terdapat aturan yang menjelaskan hak dan kewajiban keduanya berdasarkan kesepakatan. Proses untuk membuat kesepakatan dalam memenuhi kebutuhan keduanya, yaitu dengan proses untuk akad.

Menurut bahasa, akad mempunyai beberapa arti, yaitu الرَّْبط (mengikat), العَرُُْ (janji), janji adalah perbuatan yang bersifat adalah ia harus menepatinya, jika tidak, maka hubungan akibatnya adalah antara ia dengan Allah. Berbeda dengan الرَّبْط (mengikat), mengikat tidak bisa dilakukan hanya dengan satu pihak saja, tetapi harus ada pihak lain yang disambungkan atau diikatkan (Hendi Suhendi 2005: 45).

Beberapa teori etika parameter tentang baik dan buruk. Utilitarisme berasal dari kata latin utilitis yang berarti manfaat. Menurut teori ini suatu perbuatan dipandang baik jika membawa manfaat pada orang banyak (masyarakat) (Muhammad Djakfar, 2007: 19).

Deontologi berasal dari kata deon yang berarti tugas atau kewajiban. Menurut teori ini baik buruknya suatu tindakan tidak dapat ditentukan dari akibat-akibat tindakan itu, melainkan ada cara bertindak yang begitu saja terlarang atau begitu saja wajib, dasar pertimbangan baik buruknya suatu perbuatan adalah kewajiban. Etika teonom murni mengajarkan bahwa tindakan dikatakan benar (baik) bila sesuai kehendak Allah dan dikatakan salah (buruk) apabila tidak sesuai dengan kehendaknya. Delivery order atau pesan antar atau penukaran manfaat merupakan suatu kegiatan bisnis 
dalam bidang muamalah. Jasa pesan antar sebagai suatu kegiatan sewa menyewa jasanya untuk digunakan oleh seseorang, yang dapat memuaskan kebutuhan atau keinginan seseorang atau organisasi selama jangka waktu tertentu.

Ajir khas yaitu bentuk pekerjaan yang dilakukan sendiri dan bertanggung jawab sendiri pula. Bentupekerjaan seperti ini adalah pembantu rumah tangga, sopir dan termasuk jasa pesan antar (delivery).

Delivery order adalah suatu usaha perseorangan dibidang jasa. Secara umum, jenis usaha tersebut diperbolehkan, dalam Islam disebut Ijarah, lebih spesifikasinya Ijarah khusus, yang mana orang yang bekerja tidak boleh bekerja selain dengan yang memberinya upah. Maka dari unsur tersebut, penusun tertarik untuk menganalisis usaha perseorangan delivery order ditinjau dari segi etika ekonomi Islam.

Menurut Qardawi, antara ekonomi (bisnis) dan akhlak (etika) tidak pernah terpisah sama sekali, seperti halnya antara ilmu dan akhlak, antara politik dan akhlak, antara perang dan akhlak. Akhlak adalah daging dan urat nadi kehidupan Islam. Karena risalah Islam adalah risalah akhlak (Muhammad Djakfar, 2007: 21).

Etika bisnis sebenarnya telah diajarkan oleh Rasulullah SAW. Selain memilki sifat ulet dan berdedikasi dalam berdagang, beliau juga memiliki sifat shiddiq, amanah, fathanah dan tabligh.

Berbisnis merupakan aktivitas yang sangat dianjurkan dalam agama Islam . konsep dagang yang diajarkan Rasulullah SAW ialah apa yang disebut value driven yang tujuannya untuk menjaga, mempertahankan, menarik nilai-nilai dari pelanggan (Muhammad Djakfar, 2007: 193). Di zaman yang sudah banyak kemanjuan ini, kini anak-anak muda terus mengembangkan inovasinya dalam berbagai bidang demi kepuasan konsumen dan pertumbuhan perekonomian. Konsumen merasa adanya manfaat suatu kegiatan konsumsi ketika ia mendapatkan pemenuhan kebutuhan fisik atau psikis atau material (P3EI: t.t.: 129). Banyak berbagai macam bisnis yang ada, melihat kesibukan atau aktifitas masyarakat yang kian hari semakin bertambah dan kurang nya waktu untuk membeli barang kebutuhan harian maka muncul lah bisnis jasa pesan antar (delivery) barang konsumsi dan produksi.

Kini inovasi delivery terus berkembang di Indonesia salah satunya GO-JEK yang dirintis oleh Nadiem Makarim dengan menggunakan aplikasi di smartphone. Bisnis seperti ini sangat membantu ketika dalam hal tertentu. Misalnya, ketika seseorang yang sedang bekerja membutuhkan jasa untuk membeli makanan yang dikonsumsi dan mengirim barang 
dalam bentuk paket. Jasa pesan antar bisa menjadi pilihan alternatif untuk digunakan.

Dalam Islam usaha tersebut dinamakan Ijarah (menggambil manfaat). Al-Ijarah atau sewa dalam Islam diartikan sebagai akad pemindahan kepemilikan hak guna barang atau jasa, malalui pembayaran upah, tanpa diikuti pemindahan kepemilikan atas barang tersebut (Ridwan Nurdin, 2011: 85). Sebagaimana bunyi Firman Allah

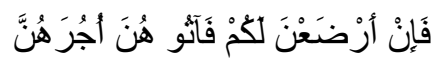

Artinya: "Jika mereka menyusukan (anak-anak) mu untukmu, maka berikanlah kepada mereka upabnya" (QS. Al-Thalaq:6)

Begitu pula di Provinsi Aceh pun sudah mulai berkembang bisnis delivery order. Di Langsa sendiri sekitar pertengahan tahun 2017 sudah mulai muncul bisnis delivery order ini, hingga sampai saat ini banyak bermunculan bisnis delivery order.

Dalam mekanisme atau cara menggunakan jasa pesan antar, pihak pemesan atau konsumen menghubungi admin delivery untuk memesan suatu barang yang diinginkan oleh konsumen dan pihak admin meneruskan pesanan (order) dalam bentuk sms atau whats app ke kurir, kurir yang akan memproses orderan konsumen. Setelah diproses, kurir akan langsung mengantarkan orderan ke alamat tujuan, dengan tarif normal Rp. 5000 per order. Dalam akadnya antara kurir dan pihak admin jasa delivery order tersebut, menggunakan sistem bagi hasil yaitu 50:50 dari pendapatan per ordernya.

Tetapi dalam prakteknya, terkadang kurir menaikkan tarif atau meminta tambahan tarif jasa kurir kepada konsumen diluar kesepakatan yang sudah ditentukan oleh pihak pengelola jasa. Oleh karena itu ada dua rumusan masalah yang ingin dijawab dalam penulisan ini, pertama adalah bagaimana praktik permintaan tambahan tarif jasa kurir dalam bisnis delivery order dan bagaimana tinjauan etika ekonomi Islam terhadap permintaan tambahan tarif jasa kurir dalam bisnis delivery order di Kota Langsa. Sedangkan metode penelitian ini adalah penelitian lapangan yaitu dalam rangka pembuktian apakah informasi awal yang telah didapat dan diamati benar adanya dan dapat dicarikan solusinya. Dalam melihat dan mencermati adanya permintaan tambahan tarif jasa kurir diluar ketentuan pihak pengelola jasa, maka dalam penelitian ini menggunakan pendekatan kualitatif. Penelitian dengan pendekatan kualitatif lebih menekankan analisisnya pada data-data pada proses penyimpulan deduktif dan induktif 
serta pada analisis terhadap dinamika hubungan antar fenomena yang diamati, dengan menggunakan logika ilmiah (Saifuddin Azwar, 2005:5).

\section{Pembahasan}

\section{Praktik Permintaan Tambahan Tarif Jasa Kurir Dalam Bisnis Delivery Order}

Langsa Provinsi Aceh pun sudah mulai berkembangnya bisnis delivery order. Sekitar pertengahan Tahun 2017 bisnis ini sudah mulai ada, hingga sampai saat ini. Kini terdapat 6 delivery order yang ada di Kota Langsa, yaitu DNK (Delivery and Kurir), Om Delivery, By Jary Delivery, Kuy Delivery, T-Jek (Tanyoe Ojek), Az-Pro Delivery. Adapun gambaran mengenai usaha jasa delivery order sebagai berikut.

Dalam usaha jasa delivery order yang ada di Kota Langsa, ada yang membentuk usahanya tersebut hanya seorang (individu) pekerja dan ada juga yang dua orang pekerja (admin dan kurir). Tugas bagi yang dua orang pekerjapun berbeda, admin bertugas sebagai mempromosikan usahanya, menerima orderan dari konsumen atau/customer, sedangkan kurir bertugas sebagai penerima orderan dari admin, membelanjakan orderan, dan mengantarkan orderan ke alamat yang telah diberikan. Setiap delivery mencantumkan tarif yang berbeda, dari Rp.5000 sampai Rp.15.000 per ordernya. Dalam akad nya antara kurir dan pihak admin jasa delivery order tersebut, menggunakan sistem bagi hasil yaitu 50:50 dari pendapatan per ordenya.

Tetapi dalam praktek nya, terkadang kurir, meminta tambahan tarif jasa kurir kepada konsumen di luar kesepakatan yang sudah ditentukan oleh pihak pengelola jasa. Misalnya tarif awal Rp.5.000 per order, tapi kurir dengan alasan karena jarak yang terlalu jauh, jumlah orderan yang banyak, disini lah kurir menaikkan atau meminta penambahan tarif menjadi Rp.7.000 per order dari pihak konsumen. Uang Rp.2.000 tersebut diambil sepenuhnya oleh kurir tanpa sepengetahuan pihak pengelola jasa delivery tersebut. Dengan melihat permasalahan tersebut, kurir bekerja dengan tidak baik, artinya kurir tidak menjalankan amanah yang diberikan oleh pemilik jasa (admin).

Kata amanah diambil dari kata "أمن" yang berarti pemeliharaan terhadap apa yang diamanahkan. Secara terminologi amanah adalah menunaikan segala sesuatu yang dititipkan dan dipercayakan kepada seseorang (Zainal Abidin, Fiddian, 2017: 122).

Seorang pebisnis haruslah dapat dipercaya, seperti yang telah dicontohkan Nabi Muhammad SAW dalam memegang amanah. Dalam dunia marketing, nilai-nilai amanah sama penting kedudukannya dengan 
nilai-nilai siddiq. Nabi Muhammad SAW telah menunjukan dirinya sebagai pedagang yang argumentatif dan komunikatif. Sehingga banyak mitra bisnis dan pelanggan merasa senang berbisnis dengannya. Lebih dari itu, Nabi Muhammad SAW mampu memberi pemahaman perihal bisnis yang sesuai dengan nilai-nilai Islam.

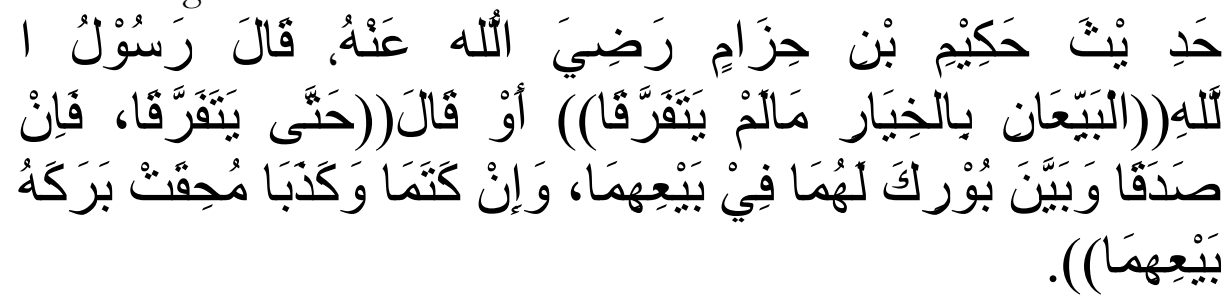

"Hakim bin Hizam r.a. berkata: Nabi Saw bersabda: penjual dan pembeli keduanya bebas selama belum berpisah atau sehingga berpisab keduanya, maka jika keduanya benar jujur dan menerangkan/terbuka maka berkat jual beli keduanya, bila menyembunyikan dan dusta dibapus berkat jual beli keduanya." (Bukhari, Muslim)

Nabi Saw menyebutkan sesuatu yang menjadi sebab adanya keberkahan dan bertambahnya keuntungan dan juga menjelaskan penyebab kerugian dan kebinasaan. Adanya keberkahan dan keuntungan serta pertumbuhan usahanya adalah hasil dari kejujuran dalam bermuamalah yaitu dengan menjelaskan dalam akad jual belinya sesuatu cacat atau kekurangan atau lainnya. Sedang sebab hilangnya keberkahan dan adanya kerugian adalah adanya penyembunyian terhadap cacatnya suatu barang dan adanya kedustaan dalam bermuamalah serta terdapat unsur penipuan.

Jasa yang ditawarkan dalam delivery order bermacam-macam, tergantung permintaan dari customer. Ada yang ingin memesan makanan, menggirim paket (kosmetik dan barang-barang olshop lainnya), dan ngojek. Cara menggunakannya pun cukup mudah, cukup mengorder melalui smartphone dengan nomor tujuan pihak layanan jasa atau admin.

Sebelum kurir menjadi mitra, pasti ada kesepakatan ataupun perjanjian antara kurir dengan pemilik usaha, yang mana dalam Islam hal tersebut dikenal dengan istilah akad. Menurut bahasa, akad mempunyai

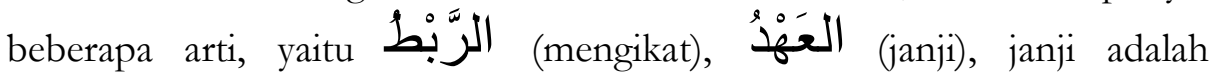
perbuatan yang bersifat sepihak. Konsekuensi yang diterima oleh orang yang berjanji adalah ia harus menepatinya, jika tidak, maka hubungan الرَّبطظ (mengikat), mengikat tidak bisa dilakukan hanya dengan satu pihak saja, tetapi harus ada pihak lain yang disambungkan atau diikatkan (Hendi 
Suhendi, 2005: 45). Menurut Kompilasi Hukum Ekonomi Syariah, yang dimaksud dengan akad adalah kesepakatan dalam suatu perjanjian antara dua pihak atau lebih untuk melakukan atau tidak melakukan perbuatan hukum tertentu (Pusat Pengkajian Hukum Islam dan Masyarakat Madani, 2009:15). Begitu juga dengan kurir, maka pastilah ada customer yang menggunakan jasanya sehingga kurir berhak atas upah yang diterimanya sebagai akibat hukum dari akad yang terjadi antara kurir dengan customer.

Dalam hukum Islam, bisnis delivery order ini dikenal dengan Ijarah (sewa-menyewa jasa).

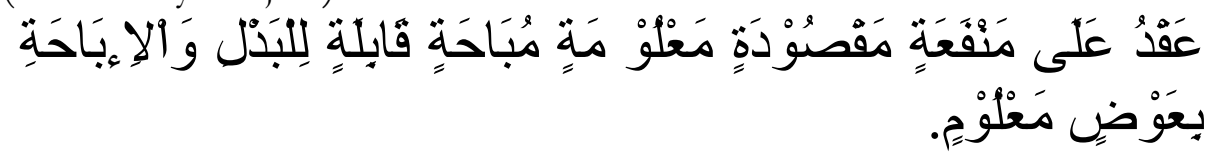

Artinya: "Akad atas sesuatu kemanfaatan yang mengandung maksud tertentu dan mubah, serta menerima pengganti atau kebolehan dengan penganti tertentu" (Taqiyuddin Abu Bakar, t.t: 249).

Hukum asal ijarah adalah mubah atau boleh, selama tidak ada halhal yang dilarang dalam Islam. Sebagaimana disebutkan dalam QS. AlQashash; 26-27.

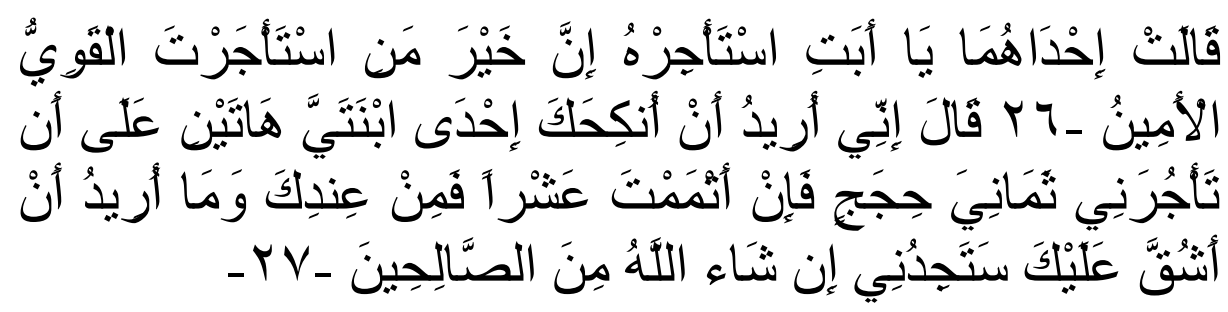

Artinya: "Salah seorang dari kedua wanita itu berkata, "Ya ayabku, ambillah ia sebagai orang yang bekerja (pada kita), karenasesunggubnya orang yang paling baik kamu ambil untuk. bekerja (pada kita) ialah orang yang kuat lagi dapat dipercaya." Berkatalah dia (Syu'aib), "Sesungguhnya aku bermaksud menikabkan kamu dari salah seorang kedua anakku ini, atas dasar bahwa kamu bekerja denganku delapan tabun. Dan jïka kamu cukupkan sepulub tabun, maka itu adalab (suatu kebaikan) dari kamu," maka aku tidak hendak memberati kamu. Dan kamu Insya Allah akan mendapatiku termasuke. orang-orang yang baik". (QS. Al-Qashash; 26-27)

Delivery order merupakan ijarah yang bersifat pekerjaan, dalam artian yang menjadi objek akad adalah pekerjaan (atau yang biasa dikenal dengan 
istilah memperkerjakan seseorang dengan upah). Orang yang melakukan pekerjaan disebut ajir, dalam delivery order ini, kurir termasuk dalam ajir khusus (orang yang bekerja selama batas waktu tertentu untuk melakukan suatu pekerjaan, dengan kata lain adalah ijarah yang dilakukan oleh seorang pekerja. Adapun yang berkerja tidak boleh melakukan pekerjaan lain untuk yang selain orang yang menyewa tenaganya). Perbuatan yang dilarang bagi pelaku usaha adalah pelaku usaha dilarang memproduksi dan/atau memperdagangkan barang dan/atau jasa yang tidak sesuai dengan janji yang dinyatakan dengan dalam label, etiked, keterangan, iklan atau promosi penjualan barang dan/atau jasa tersebut. Sehingga konsumen tidak merasa dirugikan.

Konsumen adalah setiap orang pemakai barang dan/atau jasa yang tersedia dalam masyarakat, baik bagi kepentingan diri sendiri, keluarga, orang lain, maupun makhluk hidup lain dan tidak untuk diperdagangkan. Salah satu cara yang paling utama dalam mencapai keseimbangan antara perlindungan konsumen dengan perlindungan produsen adalah menegakkan hak-hak konsumen. Konsumen akhir adalah setiap orang alami (natuurlijke persoon) yang mendapatkan barang dan/atau jasa, yang digunakan untuk tujuan memenuhi kebutuhan hidup pribadinya, keluarga dan/atau rumah tangganya dan tidak untuk diperdagangkan kembali. Sering kali produsen mengabaikan hak-hak konsumen, padahal dalam Islam dan dalam Undang-undang No 8 Tahun 1999 tentang Hukum Perlindungan Konsumen telah diatur.

Islam mengajarkan dalam sistem ekonomi umatnya, didasarkan pada nilai-nilai keadilan yang harus ditegakkan, dan menjadi prinsip pokok dalam kegiatan ekonomi. Setiap kegiatan ekonomi harus mengandung unsur manfaat serta tidak melakukan penganiayaan terhadap dirinya dan orang lain, sehingga kegiatan ekonomi dapat menciptakan kesejahteraan secara merata. Melakukan kegiatan ekonomi tidak diperbolehkan dengan melakukan penipuan, perjudian, pemaksaan, ataupun mengambil hak milik orang lain dengan cara-cara batil.

Cara mempromosikan dalam layanan delivery order itu, mereka menggunakan media sosial yang terdiri dari instagram, what's app, dan browsur. Dapat kita lihat iklan atau promosi yang diberikan oleh beberapa usaha jasa yang dibawah ini, masih terdapat kurangnya informasi yang mereka berikan, atau dengan kata lain terdapat unsur ketidakjelasan atau samar-samar. Sebagai contoh, yaitu jumlah barang dan batasan pengiriman atau batasan pertarifnya itu. Salah satu media yangg mereka gunakan yaitu instagram, bisa kita lihat pada iklan jasa Om Delivery dan By Jary Delivery. Jelas sekali bahwa informasi yang mereka berikan kepada konsumen itu masih terdapat kekurangan. Oleh sebab itu penulis 
mewawancari pihak kurir dan beberapa konsumen mengenai tambahan tarif order.

Dari hasil wawancara denga Amat TKW, tarif normal delivery itu Rp.10.000, ada penambahan tarif apabila melewati batas yang telah ia tentukan, dari simpang Comodore sampai Gp. Baro, dari Geudubang sampai Matang Selimeng, dan berbeda lagi ketika dalam kondisi hujan, dalam kondisi hujan tarifnya itu Rp.15.000. Namun ia tidak membatasi jumlah barang yang ingin dipesan, hanya saja ia membatasi untuk tempat, maksimal dua tempat, apabila lebih dari itu ia lebih sering tidak menggambil orderannya, karena menurutnya kasihan konsumen yang lain lama menunggu.

Dengan demikian peneliti ingin memberikan informasi mekanisme dari jasa DNK (Delivery and Kurir). DNK tidak hanya menerima orderan dalam bentuk makanan, terkadang juga menerima pengantaran barang dalam bentuk paket, dan kadang juga ada konsumen yang ingin diantarkan ke suatu tempat atau dikenal dengan ngojek. Sempat beberapa kurir meminta tambahan tarif kepada konsumen, karena jarak rumah konsumen cukup jauh, jumlah orderan nya yang banyak, dan alamat dari pengantaran paket yang jauh juga. Di situ lah kurir meminta tambahan tarif, yang tarif asalnya adalah Rp.5000, dan tambahannya itu Rp.2.000. Namun apabila dalam kondisi hujan, kurir tidak meminta tambahan tarif.

Untuk pembagian hasil dari jasa DNK ini, yaitu 50:50, namun ketika ada penambahan tarif, yaitu Rp.2000, kurir tidak memberinya kepada pihak admin atau manajemen. Jika dalam proses pengantaran barang yang dipesan itu rusak, maka kurir akan menggantikan dengan yang baru.

Hasil wawancara dengan ibu Liza dan Intan, sebagai pelanggan sudah 1 tahun ia menggunakan jasa delivery, biasanya ia menggunakan jasa DNK. Ia mengakui pernah diminta penambahan tarif, dikarenakan jumlah orderannya banyak. Dan dalam kondisi hujan, mereka lebih sering untuk tidak menerima orderan. Sedangkan mengenai penambahan tarif mereka merasa dirugikan dengan adanya penambahan tarif,dikarenakan tidak ada pemberitahuan sebelumnya. Sedangkan dalam promosi atau iklan sudah dicantumkan tarifnya.

Berdasarkan hasil wawancara dan observasi terhadap pihak kurir Om Delivery, By Jary Delivery, dan DNK (Delivery and Kurir) di Kota Langsa sebagaimana yang telah diuraikan di atas, maka dapat dianalisis secara kualitatif. Sikap atau respon konsumen terhadap kurir yang meminta tambahan tarif adalah konsumen merasa dibohongi ketika ada penambahan tarif dan merasa dirugikan, dikarenakan dalam informasi atau iklan yang terdapat dalam browsur ataupun media masa yang mereka berikan itu sudah tercantumkan harga atau tarifnya, apabila ia meminta lagi 
tambahan tarif berarti ia sudah melakukan pembohongan, dan konsumen menilai pada kurir yang meminta tambahan itu berarti ia bekerja tanpa menghiraukan etika bisnis yang seharusnya dijalankan.

Dalam rasionalitas Islami bahwa setiap pelaku ekonomi selalu ingin meningkatkan maslahah yang diperolehnya. Konsumen akan merasakan adanya manfaat suatu kegiatan konsumsi ketika ia mendapatkan berkah dari barang atau jasa yang dihalalkan oleh syariat Islam. Mengkonsumsi yang halal saja merupakan kepatuhan kepada Allah, karenanya memperoleh pahala. Konsumsi dalam yang Islami selalu berpedoman pada ajara Islam, tujuannya adalah di mana seorang muslim akan lebih mempertimbangkan maslahah, mengkonsumsi yang halal saja merupakan kepatuhan kepada Allah, karenanya memperoleh pahala. konsumsi diasumsikan selalu bertujuan untuk memperoleh kepuasan. Kepuasan adalah merupakan suatu akibat dari terpenuhinya suatu keinginan, sedangkan maslabah merupakan suatu akibat atas terpenuhinya suatu kebutuhan atau fitrah. Kepuasan seorang muslim tidak didasarkan banyak sedikitnya barang atau jasa yang dikonsumsi, tetapi didasarkan atas berapa nilai ibadah yang didapatkan dari yang dikonsumsinya.

\section{Tinjauan Etika Ekonomi Islam Terhadap Permintaan Tambahan Tarif Jasa Kurir dalam Bisnis Order Delivery di Kota Langsa}

Kaidah fiqh menjelaskan bahwa pada dasarnya, semua bentuk muamalah boleh dilakukan kecuali ada dalil yang mengharamkannya. Dari kaidah tersebut dapat dipahami bahwa dalam urusan dunia termasuk urusan muamalah, Islam memberikan kebebasan kepada manusia untuk mengaturnya sesuai dengan kemaslahatan mereka. Oleh sebab itu semua bentuk akad dan berbagai cara transaksi yang dibuat oleh manusia hukumnya sah dan dibolehkan, asalkan tidak bertentangan dengan ketentuan-ketentuan yang telah ada dalam syara'. Namun, dalam hukum Islam kecurangan termasuk salah satu perbuatan yang terlarang. Larangan tersebut agar seseorang tidak memakan harta orang lain secara batil dengan melakukan perbuatan yang dilarang berdasarkan hukum Islam. Allah berfirman dalam Surat An-Nisa ayat 29:

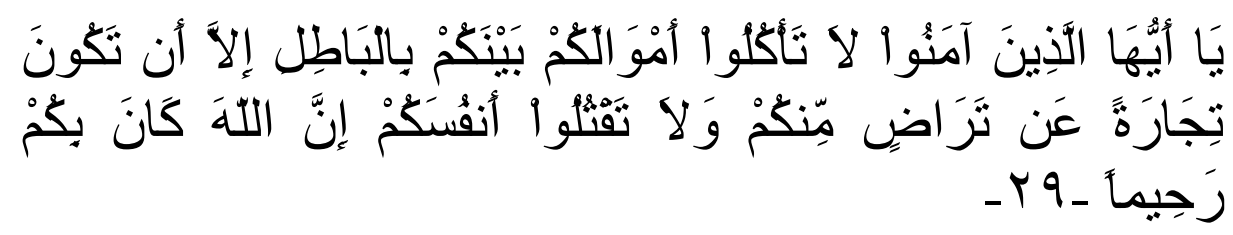

Artinya: "Hai orang-orang yang beriman, janganlah kamu saling memakan harta sesamamu dengan jalan yang bathil, kecuali dengan jalan perniagaan yang berlaku dengan suka sama suka diantar kamu. 
Dan janganlab kamu membunub dirimu, sesunggubnya Allah adalah maha penyayang kepadamu”. (Qs. An-Nisa: 29).

Ayat di atas menjelaskan bahwa, Allah mengharamkan orang beriman untuk memakan, memanfaatkan, menggunakan, (dan segala bentuk transaksi lainnya) harta orang lain dengan jalan yang batil, yaitu yang tidak dibenarkan oleh syari'at. Imam Syafi'i berkata (Muhammad bin Idris syafi'i, 2013: 2): "Allah telah menyebutkan kata jual beli dalam kitab suci-Nya, Al-Qur'an, bukan hanya pada satu tempat yang diperbolehkannya jual beli". Penghalalan Allah terhadap mengandung dua makan; salah satunya adalah bahwa Allah menghalalkan setiap jual beli yang dilakukan oleh dua orang pada barang yang diperbolehkan untuk diperjual belikan atas dasar suka sama suka. Makna yang kedua adalah, Allah Azza wa Jalla menghalalkan praktik jual beli apabila barang tersebut tidak dilarang oleh Rasulullah Saw sebagai individu yang memiliki otoritas untuk menjelaskan apa-apa yang datang dari Allah akan arti yang dikehendaki-Nya. Oleh karena itu, Rasulullah mampu menjelaskan dengan baik segala sesuatu yang dihalalkan ataupun yang diharamkan-Nya.

Adapun menurut Undang-undang Republik Indonesia Nomor 8 Tahun 1999 tentang Hukum Perlindungan Konsumen yaitu dalam Pasal 4 huruf c, yang berbunyi "Hak atas informasi yang benar, jelas, dan jujur mengenai kondisi dan jaminan barang dan/atau jasa" pihak jasa delivery order telah melanggarnya. Pemilik usaha kurang memberikan informasi yang jelas terhadap barang dan/atau jasanya kepada konsumen. Oleh sebab itu lah yang membuat konsumen merasa heran dan dirugikan ketika dimintai tambahan tarif order.

Hak-hak konsumen yang diatur dalam Undang-undang No 8 Tahun 1999 tentang Hukum Perlindungan Konsumen Pasal 4 sebagai berikut.

Hak konsumen adalah:

a. Hak atas kenyamanan, keamanan, dan keselamatan dalam mengkonsumsi barang dan/atau jasa;

b. Hak untuk memilih barang dan/atau jasa serta mendapatkan barang dan/atau jasa tersebut sesuai dengan nilai tukar dan kondisi serta jaminan yang dijanjikan;

c. Hak atas informasi yang benar, jelas, dan jujur mengenai konsidi dan jaminan barang dan/atau jasa;

d. Hak untuk didengar pendapat dan keluhannya atas barang dan/atau jasa yang digunakan;

e. Hak untuk mendapatkan advokasi, perlindungan, dan upaya penyelesaian sengketa perlindungan konsumen secara patut; 
f. Hak untuk mendapat pembinaan dan pendidikan konsumen;

g. Hak untuk diperlakukan atau dilayani secara benar dan jujur serta tidak diskriminatif;

h. Hak untuk mendapatkan kompensasi, ganti rugi dan/atau penggantian, apabila barang dan/atau jasa yang diterima tidak sesuai dengan perjanjian atau tidak sebagaimana mestinya;

i. Hak-hak yang diatur dalam ketentuan peraturan perundangundangan lainnya.

Padahal dalam Islam telah diatur mengenai hak-hak konsumen, dan hak-hak konsumen yang sering produsen abaikan. Menurut hukum Islam ada enam hak-hak konsumen yang membutuhkan perhatian serius dari pelaku usaha, yaitu (Muhammad, Alimin, 2004: 195)

a. Hak untuk mendapatkan informasi yang benar, jujur, adil, dan terhindar dari pemalsuan,

b. Hak untuk mendapatkan keamanan produk dan lingkungan sehat,

c. Hak untuk mendapatkan advokasi dan penyelesaian sengketa,

d. Hak untuk mendapatkan perlindungan dari penyalahgunaan keadaan,

e. Hak untuk mendapatkan ganti rugi akibat negatif dari suatu produk,

f. Hak untuk memilih dan memperoleh niai tukar yang wajar.

Berdasarkan hak-hak di atas, dalam kajian fiqh Islam kebenaran dan keakuratan informasi ketika seorang pelaku usaha mempromosikan barang dagangannya menempati kajian signifikan. Islam tidak mengenal bahwa konsumen yang harus berhati-hati atau sebaliknya pelaku usahalah yang harus berhati-hati. Di dalam Islam yang berlaku hanyalah prinsip keseimbangan. Di sini antara kedua belah pihak konsumen maupun pelaku usaha harus sama-sama berhati-hati.

Dalam hukum Islam, praktik yang dilakukan antara kurir dan customer disebut dengan ijarah (sewa-menyewa) dalam lingkup jasa. Ijarah adalah akad pemindahan hak guna guna atas barang dan jasa, melalui pembayaran upah sewa, tanpa diikuti dengan pemindahan kepemilikan atas barang itu sendiri. Namun dalam hal ini objeknya adalah jasa atas pekerjaan seseorang. Tarif adalah salah satu bentuk imbalan atas customer sebagai ganti atas sesuatu pekerjaan atau jasa karena telah membelanjakan, mengantarkan ketempat tujuan. 
Rukun dan syarat merupakan sesuatu yang mesti ada dalam sebuah akad atau transaksi. Tanpa rukun akad tidak akan sah. Layaknya sebuah transaksi ijarah dapat dikatakan sah apabila memenuhi rukun dan syarat. Salah satu rukun ijarah adalah hak atas pekerja atau yang dikenal dengan upah atau ujrah, yakni di mana orang yang memiliki jasa atau melakukan sesuatu pekerjaan akan mendapat imbalan dari orang yang menyewa jasa. Pada praktiknya tarif atau ongkos sudah diketahui oleh customer sebelum melakukan pemesanan, dan tarif itulah yang harus dibayarkan oleh customer kepada kurir sebagai imbalan atas jasa yang telah dilakukan. Upah atau wirah dalam Islam ada dua macam salah satunya upah yang telah disebutkan (ujrah al-musamma) (Taqiyuddin an-Nabhani, 1996: 103). Upah yang disebut, syaratnya ketika disebutkan harus disertai dengan adanya kerelaan (diterima) kedua belah pihak yang sedang melakukan transaksi terhadap upah tersebut.

Dengan demikian, pihak musta'jir tidak boleh dipaksa untuk membayar lebih besar dari pada apa yang disebutkan, sebagaimana pihak mu'jir juga tidak boleh dipaksa untuk mendapatkan lebih kecil dari apa yang telah disebutkan. Pada penerapannya, upah atau ujrah yang akan dibayar oleh customer kepada kurir telah disebutkan pada bentuk promosi sebagai informasi yang mereka berikan. Namun kenyataannya terdapat beberapa oknum kurir dan delivery yang melakukan penambahan tarif di luar tarif yang telah ditentukan karena masalah jarak tempuh yang lumayan jauh, jumlah orderan yang banyak dan terkadang dalam kondisi hujan, sehingga membuat customer menjadi terpaksa untuk membayar lebih besar dari pada apa yang disebutkan dalam informasi.

Jika ditinjau dari segi syarat ijarah yang pertama, yaitu kedua orang yang berakad, pada praktik ini dinyatakan sah karena adanya customer dan kurir. Tanpa adanya costumer sewa menyewa jasa tidak akan terjadi, begitu juga sebaliknya. Kemudian syarat yang kedua, kedua belah pihak yang berakad menyatakan kerelaannya untuk mengatakan akad ijarah. Apabila di antara salah satunya terpaksa melakukan akad itu, maka akad itu tidak sah. Hal ini jika dikaitkan dengan masalah tambahan tarif jasa kurir maka tidak sesuai dengan syarat ijarah yang kedua. Karena adanya tambahan tarif yang dilakukan oleh oknum delivery dan kurir memaksa customer untuk membayar lebih dari tarif yang telah ditetapkan. Seperti yang disampaikan oleh saudara Aziz pada saat wawancara, karena kondisi malam dan hujan juga akhirnya dia terpaksa untuk membayar lebih mahal dari apa yang telah ditetapkan. Kemudian seperti yang sampaikan oleh saudari Intan saat wawancara, ia pernah dimintai tambahan tarif, dikarenakan jumlah orderannya yang banyak, akhirnya ia terpaksa untuk membayarnya. Bisa dilihat bahwa customer kurang rela dengan tambahan tarif tersebut, 
dikarenakan tidak ada pemberitahuan sebelumnya, tetapi karena memang sudah perlu akhirnya customer pun mau tidak mau harus membayarnya.

Dalam informasi yang diberikan oleh pihak manajemen delivery masih terdapat unsur gharar (ketidakjelasan), di mana dalam promosinya tidak disebutkan dengan rinci dan jelas mengenai usahanya tersebut, misalnya batasan wilayah, maksimal tempat orderan dan jumlah barang yang boleh dipesan. Secara bahasa, gharar berarti hal yang tidak diketahui nahaya tertentu atau jual beli barang yang mengandung kesamaran. Menurut terminologi atau istilah fiqihnya, gharar diartikan oleh para Ulama ahli fiqh seputar hal ketidaktahuan terhadap akibat suatu perkara/transaksi, atau ketidakjelasan antara baik dan buruknya atau jual beli mengandung kesamaran (Imam al-Zabidi, 1997:457). Sesuatu yang bersifat spekulasi atau samar-samar haram untuk diperjualbelikan, karena dapat merugikan salah satu pihak, baik penjual maupun pembeli. Adapun yang dimaksud dengan samar-samar adalah tidak jelas, baik barangnya, harganya, kadarnya, masa pembayarannya, maupun ketidakjelasan yang lainnya (Wahbah az-Zuhaili, 3495: 2011).

Hukum jual beli gharar sudah jelas bahwa Rasulullah SAW telah melarangnya. Karena jual beli itu pada dasarnya harus jelas dan terhindar dari suatu ketidakpastian. Sebagaimana larangan Rasulullah SAW dalam hadistnya yang berbunyi:

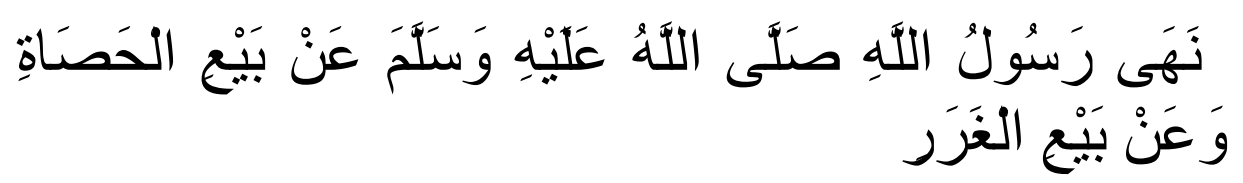

Artinya: "Rasulullah telah melarang melakukan jual beli hashah (melempar kerikil) dan jual beli barang secara gharar".(HR. Muslim: t.t: 1513)

Sebagian ulama mutaakbbirin telah mentarjihkan definisi gharar dengan memilih pendapat Ibnu Taimiyah dan As-Syarkhasyi yang mengatakan bahwa al-gharar adalah bila hasil akhirnya tersembunyi. Bisa dilihat kepada beberapa definisi yang juga menyebutkan contoh-contoh kasus tentang gharar, bahwa gharar adalah tersembunyi hasil akhirnya dan adanya keraguan pada dua probabilitas (Al-Khanuji, 1996: 197).

Hasil akhir yang tersembunyi sangat dipengaruhi oleh adanya informasi yang tidak sempurna pada mereka yang bertransaksi. Seperti definisi Zamir Iqbal dan Abas Mirakhor, gharar adalah situasi dimana pihak-pihak yang terikat kontrak atau salah satu dari mereka tidak memiliki informasi berkaitan dengan pasal dalam akad atau pasal dalam 
kontrak, dan cenderung tidak mampu dikontrol oleh salah satu pihak (Zami Iqbal, Abas Mirakhor, 2008: 88). Bagi Adiwarman Karim, hal ini bersumber dari ketidaksamaan pada informasi pada pihak-pihak yang bertransaksi, sehingga melahirkan ketidakpastian yang diciptakan oleh kekurangan informasi atau tidak adanya kontrol dalam akad (Adiwarman karim, 2011: 31). Gharar fish shifah yakni spekulasi jenis, seperti menjual barang yang tidak jelas jenisnya. Agar terhindari dari gharar fish shifah, maka dalam setiap barang atau jasa haruslah dijelaskan secara rinci mengenai barang dan jasa tersebut.

Jika kita melihat dari segi teori utilitarisme (bermanfaat), perbuatan yang dilakukan oleh pihak kurir itu merupakan perbuatan yang kurang tepat. Karena utilitarisme itu sendiri adalah suatu perbuatan dipandang baik jika membawa manfaat pada orang banyak (masyarakat). Ini berarti bahwa jika perbuatan itu hanya membawa kepada segelintir orang, maka perbuatan perbuatan itu tidak termasuk dalam perbuatan yang baik. Menurut utilitarisme suatu perbuatan baru dapat dinilai jika akibat dan tujuan sudah ditetapkan. Dasar argumen bahwa manusia itu tidak hidup sendiri melainkan hidup bersama-sama. Apabila ada kebijakan atas nama bersama, maka kepentingan pribadi harus tunduk pada kepentingan bersama. Karena perbuatan itu lebih mendatangkan kebahagian kepada banyak orang (Daniel Kolak, Garret Thomson, 2006:836). Dan jika dilihat pada perspektif etika bisnis Islam dianggap telah melakukan penipuan. Yang mana dalam point itu disebutkan "menetapkan harga dengan transparan". Harga yang tidak transparan bisa mengandung penipuan.

Salah satu hak konsumen dalam Islam adalah hak untuk memilih yang dikenal dengan istilah kbiyar. Memalui hak kbiyar in, Islam memberikan ruang yang cukup luas bagi konsumen dan produsen untuk mempertahankan hak-hak mereka dalam perdagangan apakah melanjutkan aqad/transaksi bisnis atau tidak. Khiyar yang berlaku untuk permasalahan di atas adalah khiyar majlis. Pengertian khiyar majlis sebagaimana dikemukakan oleh Sayid Sabiq (Sayid Sabiq, 1981: 164) adalah kbiyar yang diberikan kepada kedua belah pihak yang melakukan akad untuk meneruskan atau membatalkan jual beli selama mereka masih berada di majlis akad, setelah terjadinya ijab dan qabul, dengan syarat tidak ada perjanjian tidak khiyar.

Dasar hukum khiyar majlis ini adalah sabda Rasulullah Saw, yang berbunyi: 


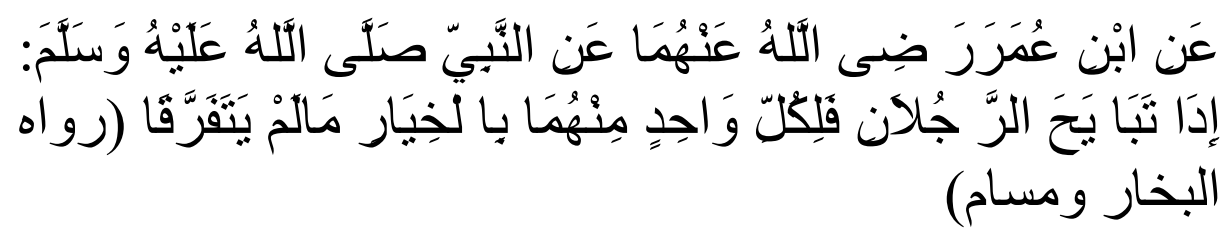

Artinya: "Dari ibnu Umar r.a Nabi Saw bersabda: bila dua orang berjual beli, masing-masing boleh kbiyar (jadi atan tidaknya jual beli), selama keduanya belum bercerai dari tempat akad". (H.R. Bukhari dan Muslim, t.t: 18)

Ketika jual beli berlangsung, masing-masing pihak berhak melakukan khiyar antara membatalkan atau meneruskan akad hingga berpisah atau menentukan pilihan. Perpisahan terjadi apabila kedua belah pihak memalingkan badan untuk meninggalkan tempat transaksi.

\section{Kesimpulan}

Dalam pembahasan yang telah penulis paparkan di atas maka dapat disimpulkan bahwa praktik penamnahan tarif yang dilakukan oleh pihak manajemen dan kurir delivery order diketahui bahwa penambahan tarif hanya dibebankan kepada konsumen atau costomer yang beralamat lebih jauh, jumlah orderan yang banyak dan ketika kondisi hujan. Adapun penambahan biaya di luar tarif yang ditetapkan dengan besaran Rp.2000 sampai Rp.10.000 maka konsumen merasa dirugikan, sebab sebelumnya tidak ada pemberitahuan ketentuan-ketentuan yang berlaku.

Sedangkan penambahan tarif jasa kurir jika ditinjau menurut etika hukum ekonomi Islam, praktik yang dilakukan antara kurir dan costomer termasuk dalam akad ijarah (sewa menyewa) dalam bidang jasa. Layaknya sebuah transaksi ijarah dapat dikatakan sah apabila memenuhi rukun dan syaratnya. Salah satu rukun ijarah adalah hak atas pekerja atau yang dikenal dengan ujrah. Ujrah al-Musamma adalah upah yang telah disebutkan. Upah tersebut ketika disebutkan harus disertai dengan adanya kerelaan ('An taraadbin) atau diterima oleh kedua belah pihak yang sedang melakukan transaksi terhadap upah tersebut. Pihak mustajir tidak boleh dipaksa untuk membayar lebih besar dari pada apa yang telah disebutkan, sebagaimana pihak mu'jir juga tidak boleh dipaksa untuk mendapatkan lebih kecil dari apa yang telah disebutkan. Dalam usaha jasa delivery order ini, pihak manajemen tidak menjelaskan secara rinci tentang ketentuanketentuan usahanya, artinya masih terdapat unsur gharar (ketidakjelasan). Oleh karena itu, hak konsumen yang telah diatur dalam UUPK pasal 4 huruf $\mathrm{c}$ dan juga menurut tinjauan hukum ekonomi syariah hak untuk 
mendapatkan informasi yang benar, jelas, jujur dan adil tidak dapat dilaksanakan oleh pihak delivery order. 


\section{DAFTAR PUSTAKA}

Adiwarman Karim. 2011. Islamic Banking: Figh dan Financial analysis, Jakarta: Rajawali Press, Ed. 4.

Al-Bukhari. t.t. Shahih Bukhari, Indonesia: Maktab Dahlan.

Daniel Kolak \& Garret Thomson. 2006. On Liberty, The Longman Standar History Of Philosophy, New York: Pearson Longman.

Hendi Suhendi. 2005. Fiqh Muamalah, Jakarta: PT Raja Grafindo Persada.

HR. Muslim. t.t. Kitab Al-Buyu', Buthlan Bai Al-Hashah wal Bai Alladzi fibi Gharar, 1513.

Imam al-Zabidi. 1997. Ringkasan Shabih al-Bukhari, Terj. Bandung: Mizan Media Utama.

Imam Syafi'i Abu Abdullah Muhammad bin Idris. 2013. Ringkasan Kitab Al-Umm, terj. Imron Rosadi ddk, Cet ke-10, Jakarta: Pustaka Azzam.

Muhammad \& Alimin. 2004. Etika dan Perlindungan konsumen dalam Ekonomi Islam, Yogyakarta: BPFE.

Muhammad Djakfar. 2007. Etika Bisnis dalam Perspektif Islam Malang: UIN Malang Press.

Muhammad Shiddiq Hasan Khan Al-Khanuji. 1996. Al-Raudah al-Nadiyah Sharh al-Darar al-Bahiyah, Riyadh: Maktabah al-kautsar, Cet. 4, Jil.2.

Pusat Pengkajian dan Pengembangan Ekonomi Islam-P3EI-Ekonomi Islam. t.t. Jakarta: PT Raja Grafindo Persada.

Pusat Pengkajian Hukum Islam dan Masyarakat Madani. 2009. Kompilasi Hukum Ekonomi Syariah, Jakarta: Kencana Persada Media Grup.

Ridwan Nurdin. 2011. Fiqh Muamalah, Banda Aceh: Pena.

Saifuddin Azwar. 2005. Metode Penelitian, Yogyakarta Pustaka Pelajar.

Sayid Sabiq. 1981. Fiqh As-Sunnah, Juz 3, Beirut: Dar Al-Fikr, cet 3.

Taqiyuddin Abu Bakar bin Muhammad. t.t. Kifayah Al-Akbyar fi Hilli Ghayah Al-Ikhsir, Juz 1, Surabaya: Dar Al-Ilmi.

Taqiyuddin an-Nabhani. 1996. Membangun Sistem Ekonomi Alternatif PerspektifIslam, Terj. Surabaya: Risalah Gusti.

Wahbah az-Zuhaili. 2005. Al-Fiqh al-Islami wa Adillatubu, Jil. 5 cet. Ke-8 Damaskus: Dar-al-Fikr al-Mu'ashir.

Zainal abidin, Fiddian Khairudin. 2017. "Penafsiran Ayat-ayat Amanah Dalam Al-Qur'an”, Jurnal Syahadah, Vol. V, No. 2.

Zami Iqbal dan Abas Mirakhor. 2008. An Introduction to Islamic Finance: Theory and Practice, Terj. A.K Anwar dengan judul Pengantar Keuangan Islam: Teori dan Praktek, Jakarta: Kencana, Cet.1. 